\title{
APLIKASI PRODUK GEOSINTETIK UNTUK PEKERJAAN REKLAMASI PANTAI
}

\author{
Andryan Suhendra \\ Fakultas Teknik Sipil Universitas Bina Nusantara \\ asuhendra@binus.edu
}

\begin{abstract}
Besides opening new land to the hilly terrain, reclamation of beach and other watery land is one of the alternatives of residential land compliance which is pretty much applied. However, the reclamation work often encounteres some obstacles, such as the soft subgrade with a low carrying capacity and the possibility for consolidation reduction which is large and long and high sea waves that could potentially cause abrasion during both construction and after construction. The use of geosynthetic materials as an alternative material supporting the reclamation work in Indonesia is still limited. The project owner and executives tend to use conventional methods though the use of geosynthetic can provide benefits and ease of implementation. Some of the advantages of using geosynthetic materials in reclamation work with soft soil foundation is a faster execution of the work, loss reduction of embankment material into the soft subgrade, and lower maintenance costs. This paper discusses geosynthetic products as well as its application to the reclamation work that comes with examples of projects that have been or are being carried out and in Indonesia.
\end{abstract}

Keywords: reclamation, geosynthetic, soft soil, abrasion

\begin{abstract}
ABSTRAK
Selain membuka lahan baru ke arah daerah perbukitan, reklamasi pantai dan lahan berair lainnya merupakan salah satu alternatif pemenuhan lahan tempat tinggal yang cukup banyak diterapkan. Namun seringkali pekerjaan reklamasi ini menemui beberapa kendala, seperti tanah dasar yang lunak dengan daya dukung yang rendah dan potensi penurunan konsolidasi yang besar dan lama serta gelombang laut yang tinggi yang berpotensi menyebabkan abrasi baik selama masa konstruksi maupun masa pelayanan. Penggunaan material geosintetik sebagai salah satu alternatif material pendukung pada pekerjaan reklamasi di Indonesia masih terbatas. Para pemilik proyek dan pelaksana proyek cenderung menggunakan metode konvensional. Padahal penggunaan geosintetik dapat memberikan keuntungan dan kemudahan dalam pelaksanaan proyek. Beberapa keuntungan dari penggunaan material geosintetik pada pekerjaan reklamasi pantai dengan kondisi tanah dasar yang lunak adalah pelaksanaan pekerjaan yang lebih cepat, pengurangan kehilangan material timbunan ke dalam tanah dasar yang lunak, dan biaya pemeliharaan yang lebih rendah. Makalah ini membahas mengenai produk-produk geosintetik serta aplikasinya pada pekerjaan reklamasi pantai yang dilengkapi dengan contoh proyek yang sudah dan atau sedang dikerjakan di Indonesia.
\end{abstract}

Kata kunci: reklamasi, geosintetik, tanah lunak, abrasi 


\section{PENDAHULUAN}

Reklamasi pantai adalah proses membuat daratan baru pada daerah perairan, pesisir pantai ataupun di daerah rawa (Gambar 1). Reklamasi merupakan pilihan yang saat ini populer dalam pengembangan wilayah kota-kota besar yang mempunyai daerah yang berbatasan dengan laut seperti Jakarta, Surabaya, Makasar dan Manado. Hasil pekerjaan reklamasi bisa dimanfaatkan untuk sarana pemukiman, kawasan industri, pelabuhan, bandara dan kebutuhan pengembangan wilayah lainnya.

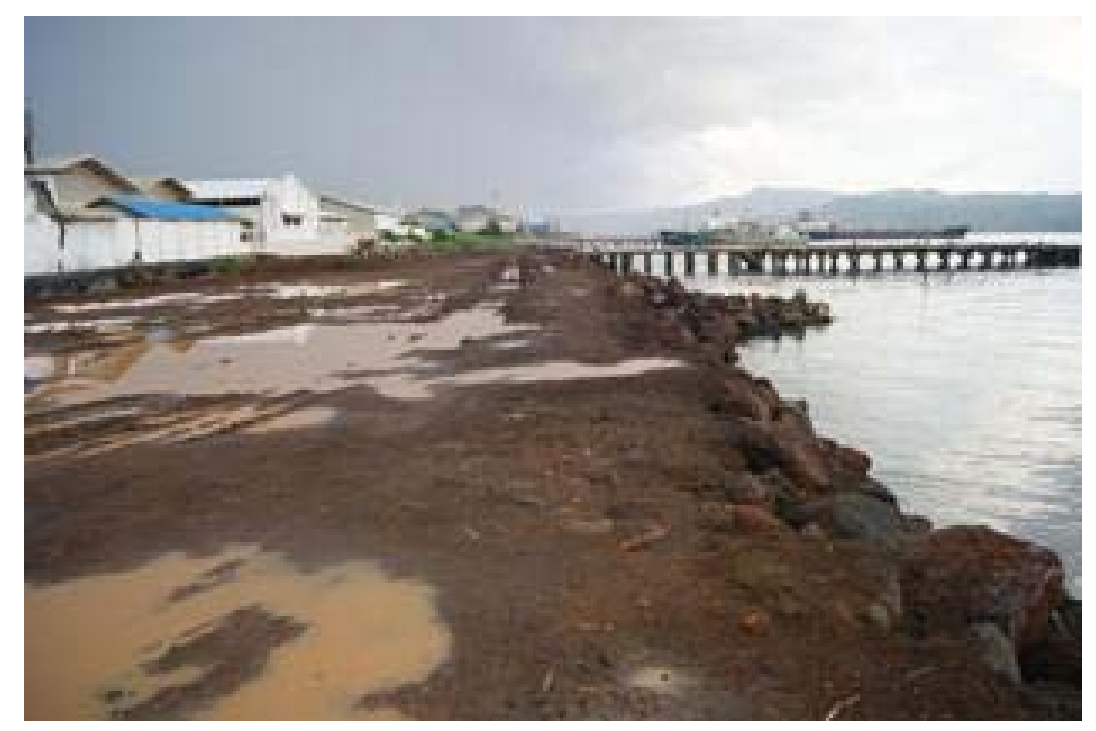

Gambar 1 Contoh reklamasi pantai (sumber: www.suarasulut.com)

Pekerjaan reklamasi harus dilakukan dengan disain dan metode konstruksi yang baik sehingga hasilnya bisa dipertanggung jawabkan secara teknis, ekonomis dan tanpa menimbulkan dampak negatif terhadap keselarasan lingkungan hidup. Pemilihan peralatan dan material yang tepat sangat diperlukan untuk menunjang metode konstruksi yang cocok.

Mengacu pada Buku Pedoman Reklamasi di Wilayah Pesisir (2005) terbitan Direktorat Jenderal Kelautan, Pesisir dan Pulau-Pulau Kecil (dikutip dari makalah bapak Dr.Ir.Ruchat Deni Djakapermana M.Eng - Sekretaris Direktorat Jenderal Penataan Ruang), ada empat sistem reklamasi, yaitu: (1) sistem timbunan, yaitu menimbun perairan pantai sampai elevasi permukaan lahan berada di atas muka air laut paling tinggi; (2) sistem polder, yaitu mengeringkan perairan yang akan direklamasi dengan memompa air yang berada didalam tanggul kedap air untuk dibuang keluar dari daerah lahan reklamasi; (3) sistem kombinasi antara polder dan timbunan, yaitu setelah dikeringkan dengan metode pemompaan, lahan ditimbun sampai ketinggian tertentu sehingga perbedaan elevasi antara lahan reklamasi dan muka air laut tidak besar; (4) sistem drainase, sistem ini umumnya dipakai untuk wilayah pesisir yang datar dan relatif rendah dari wilayah di sekitarnya tetapi elevasi muka tanahnya masih lebih tinggi dari elevasi muka air laut.

Untuk mendapatkan hasil disain yang memuaskan perlu dilakukan investigasi pada areal yang akan direklamasi yang mencakup kondisi tanah dasar, tinggi gelombang air laut, ketersediaan material reklamasi dan lain sebagainya. Melalui proses investigasi yang baik, akan dapat diketahui berbagai permasalahan yang mungkin terjadi, sehingga dapat dilakukan analisis secara detail untuk mendapatkan metode konstruksi yang sesuai dan tepat guna. 
Proses reklamasi pada daerah pantai umumnya diawali dari pembuatan tanggul di sisi laut untuk mencegah hilangnya material timbunan tersapu oleh arus dan gelombang laut, yang dilanjutkan dengan proses penimbunan (baik dari sisi darat maupun dari sisi laut) hingga mencapai elevasi rencana. Reklamasi yang dilakukan harus dapat memberikan manfaat ekonomis, sekaligus memberikan nilai tambah pada pelestarian lingkungan.

\section{METODE}

Penelitian yang dilakukan adalah dengan mengumpulkan dan menyarikan beberapa sistem yang sesuai dengan aplikasi material geosintetik pada pekerjaan reklamasi.

\section{Permasalahan pada Proses Reklamasi}

Beberapa permasalahan yang mungkin dihadapi pada pekerjaan reklamasi pantai baik pada saat pelaksanaan reklamasi maupun untuk kondisi jangka panjang yaitu sebagai berikut: (1) stabilitas timbunan yang rendah; (2) penurunan konsolidasi yang besar dalam waktu yang panjang; (3) abrasi; (4) pencemaran lingkungan (laut) sekitar.

\section{Stabilitas Timbunan yang Rendah}

Tanah dasar yang lunak serta tebal lapisan reklamasi yang tinggi mempunyai kecenderungan menyebabkan rendahnya stabilitas timbunan yang pada akhirnya dapat menyebabkan terjadinya kelongsoran pada tubuh timbunan (Gambar 2).
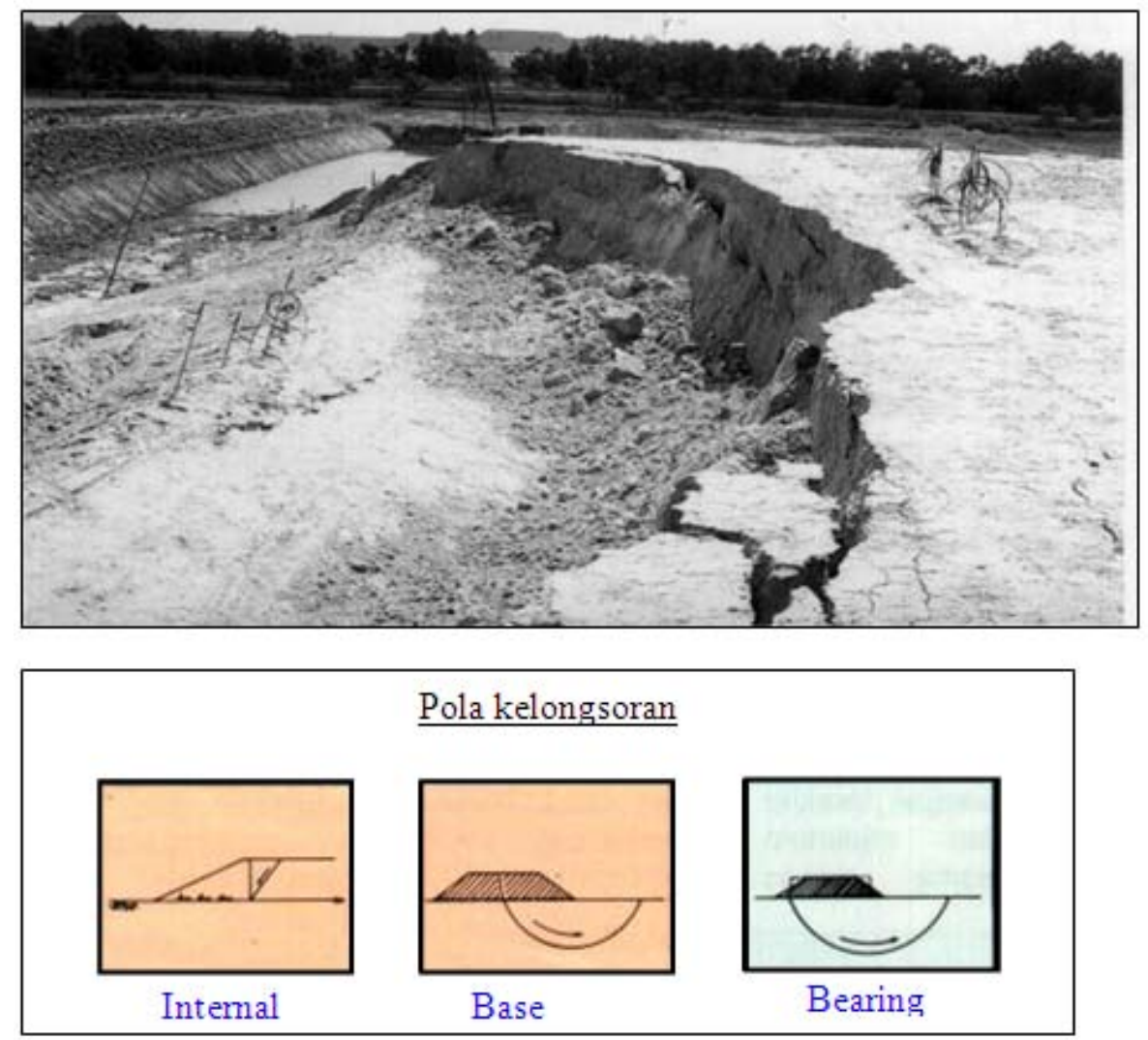

Gambar 2 Kelongsoran pada timbunan 
Untuk mengetahui potensi dari kemungkinan terjadi kelongsoran pada tubuh timbunan reklamasi dapat dilakukan analisis geoteknik melalui penggunaan beberapa formula yang diperkenalkan oleh beberapa ahli geoteknik seperti Bishop, Morgenstein, dan lain sebagainya serta dapat pula menggunakan piranti lunak komputer seperti program Geo Studio (Gambar 3), Plaxis (Gambar 4), dan lain sebagainya.

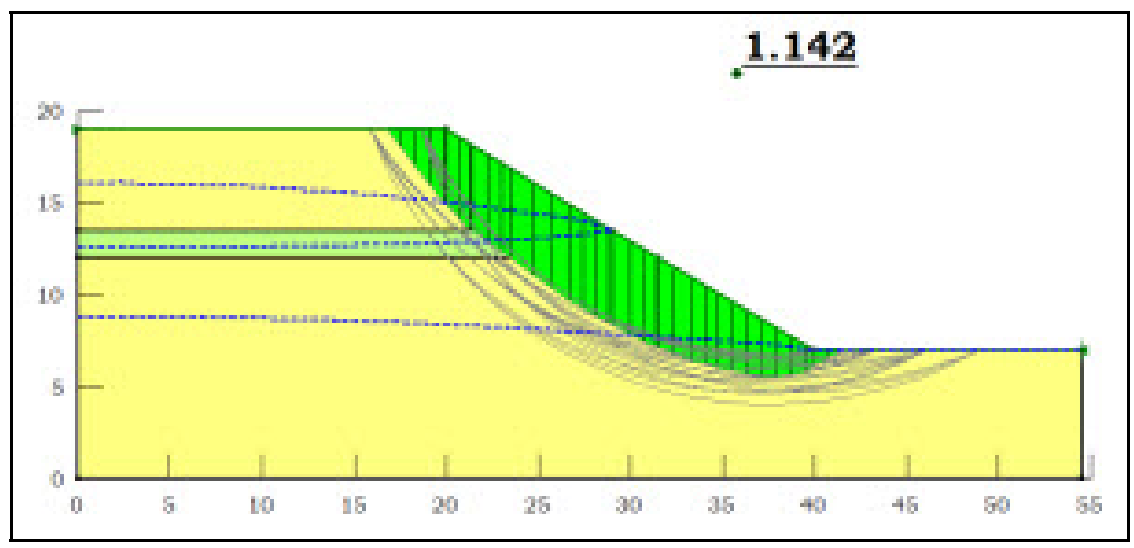

Gambar 3 Contoh hasil analisis stabilitas timbunan menggunakan Geo Studio

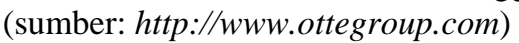

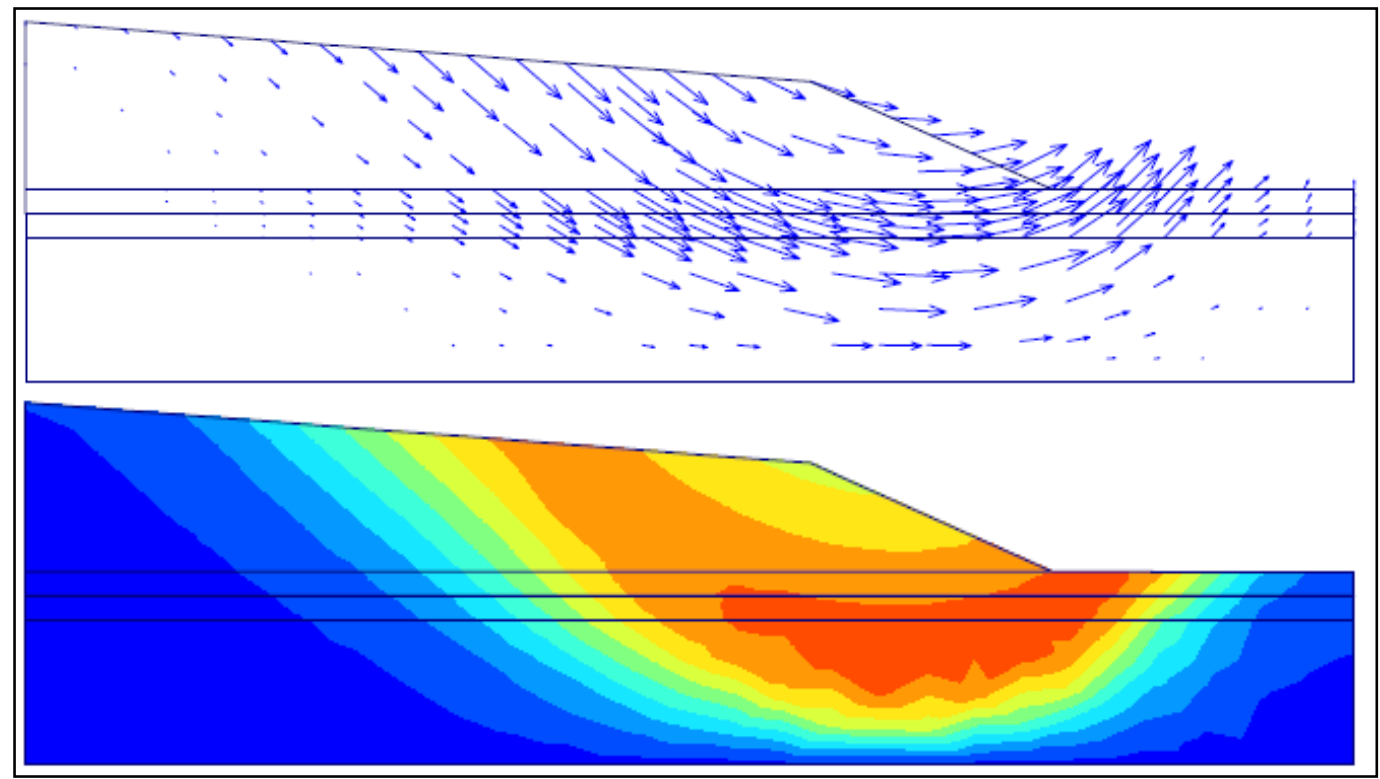

Gambar 4 Contoh hasil analisis stabilitas timbunan menggunakan Plaxis

\section{Penurunan Konsolidasi yang Besar dalam Waktu yang Panjang}

Permasalahan lain yang dihadapi pada pekerjaan reklamasi pantai di atas tanah lempung lunak adalah kemungkinan terjadi penurunan konsolidasi. Penurunan konsolidasi merupakan proses disipasi air pori tanah akibat tambahan beban yang berakibat pada peristiwa pemampatan/penurunan lapisan tanah. Proses disipasi air pori ini sangat tergantung dari kemampuan tanah untuk mengalirkan air (permeabilitas tanah), umumnya tanah lempung mempunyai kemampuan pengaliran air yang relatif rendah sehingga proses konsolidasi ini umumnya membutuhkan waktu yang relatif panjang. 
Dampak dari penurunan konsolidasi yang besar dan lama ini terhadap struktur yang akan dibangun di atas tanah timbunan adalah kegagalan konstruksi seperti terlihat pada Gambar 5 berikut ini. Sedangkan pada kasus konstruksi timbunan, dibutuhkan proses penimbunan secara berulang pada masa pemeliharaan untuk menjaga elevasi permukaan timbunan tetap pada posisi yang direncanakan.

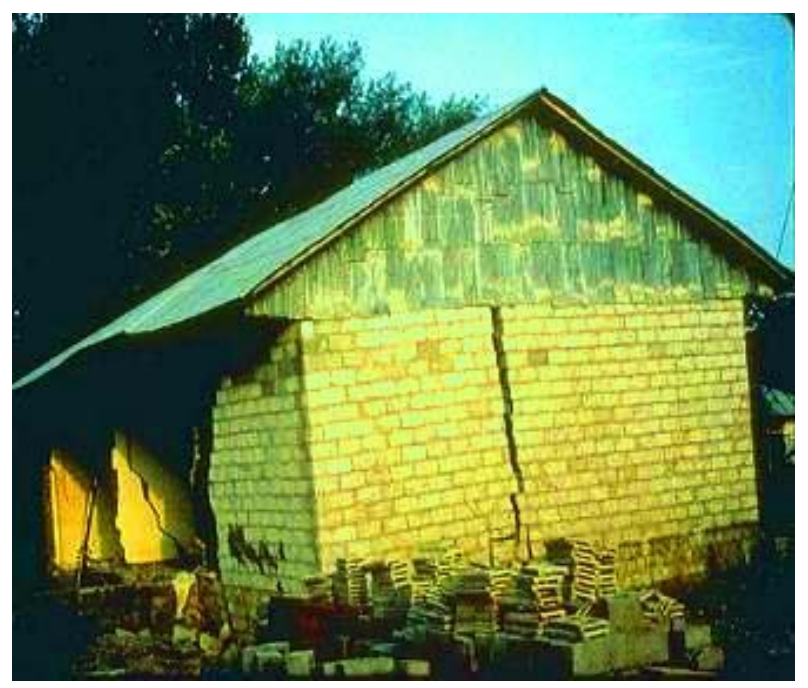

Gambar 5 Contoh kasus kegagalan konstruksi akibat penurunan konsolidasi (sumber: http://civil-engg-world.blogspot.com)

Untuk memperkirakan besar penurunan konsolidasi, dapat digunakan formula yang diperkenalkan oleh Terzaghi (Das, 2001) sebagai berikut:

Tanah Lempung terkonsolidasi secara normal (normal consolidated clay)

$$
S_{c}=\frac{C c}{1+e o} H_{c} \log \left(\frac{\sigma_{o}{ }^{\prime}+\Delta \sigma}{\sigma_{o}{ }^{\prime}}\right)
$$

Tanah Lempung terkonsolidasi berlebih (over consolidated clay)

Kasus 1

$$
S_{c}=\frac{C s}{1+e o} H_{c} \log \left(\frac{\sigma_{o}{ }^{\prime}+\Delta \sigma}{\sigma_{o}{ }^{\prime}}\right)
$$

Kasus 2

$$
S_{c}=\frac{C s}{1+e o} H_{c} \log \left(\frac{\sigma_{c}}{\sigma_{o}{ }^{\prime}}\right)+\frac{C c}{1+e o} H_{c} \log \left(\frac{\sigma_{o}{ }^{\prime}+\Delta \sigma}{\sigma_{c}}\right)
$$

Sedangkan waktu penurunan konsolidasi dapat diperkirakan dengan menggunakan formula dari Terzaghi berikut ini.

$$
t=\frac{T_{v} \cdot H^{2}}{C_{v}}
$$

\section{Abrasi}

Konstruksi timbunan yang terletak di tepi laut mempunyai kecenderungan mengalami abrasi (Gambar 6) akibat peristiwa pasang surut atau gelombang air laut yang menghempas pantai. Hal yang 
sama juga sangat mungkin dialami oleh konstruksi timbunan hasil reklamasi, sehingga perlu dilakukan suatu tindakan preventif guna mengamankan konstruksi timbunan reklamasi yang telah direncanakan dan dilaksanakan.

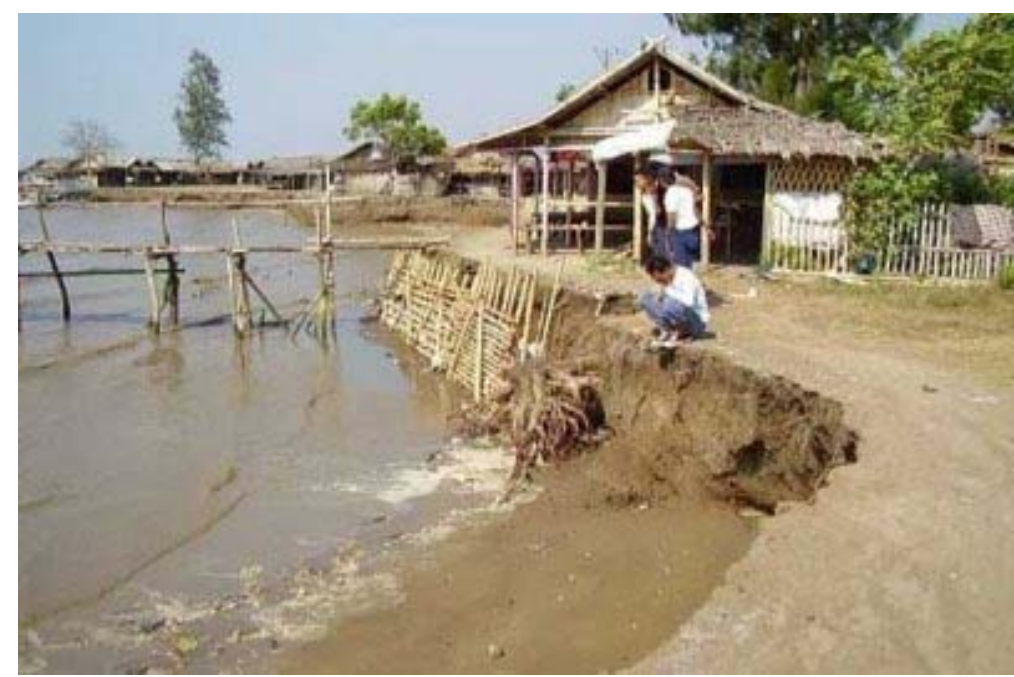

Gambar 6 Abrasi akibat peristiwa pasang surut dan hempasan gelombang (sumber: http://cempaka-marine.blogspot.com)

\section{Pencemaran Lingkungan (Laut) Sekitar}

Material reklamasi yang didapat dari daratan ataupun hasil "dredging” laut seringkali mengandung partikel-partikel halus yang ringan, yang mempunyai kecenderungan terapung atau melayang sehingga dapat mencemari atau mengotori air laut di sekitar areal reklamasi serta dapat menganggu ekosistem di sekitarnya (Gambar 7).

Hal yang sama juga mungkin terjadi pada kondisi tanah dasar yang mengandung sedimen (partikel halus), partikel halus ini mempunyai potensi berhamburan pada proses penimbunan (reklamasi) dan mencemari perairan.

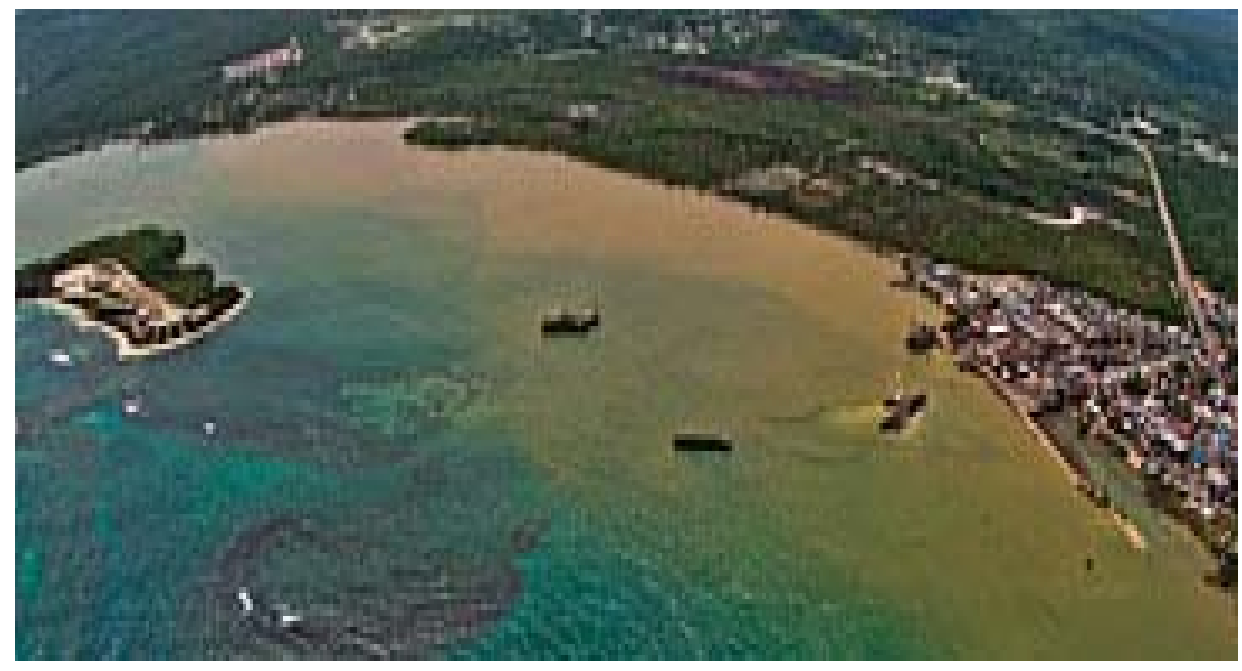

Gambar 7 Contoh pencemaran laut pada proses reklamasi (Sumber: http://www.mottmac.com) 


\section{Material Geosintetik}

Geosintetik merupakan material teknik yang terbuat dari polimer-polimer sintetik seperti polipropilin (PP), poliester (PET), polietilin (PE) dan lain sebagainya, yang digunakan pada berbagai pekerjaan geoteknik termasuk pada pekerjaan reklamasi pantai di atas tanah lunak (Lawson, 2012).

Berbagai jenis material geosintetik dapat dan sudah diterapkan pada pekerjaan reklamasi pantai di atas tanah lunak sesuai dengan fungsi dari masing-masing jenis material geosintetik tersebut. Berikut ini beberapa jenis material geosintetik dan fungsinya pada pekerjaan reklamasi pantai di atas tanah lunak.

\section{Geotextile Containment}

Geotextile containment (Koerner, 2005) merupakan suatu konstruksi yang memadukan antara material sintetik (geotekstil) dan material alam (pasir atau Lumpur). Pada pekerjaan reklamasi pantai, sistem ini berfungsi sebagai dinding penahan tanah dan pencegah terjadinya abrasi, dikerjakan sebelum pekerjaan reklamasi dilaksanakan.

Ada tiga jenis konstruksi geotextile containment dengan pembagian berdasarkan ukuran dan cara pelaksanaan konstruksi yaitu sebagai berikut:

Pertama adalah Geobag. Geobag merupakan jenis dari geotextile containment dengan volume yang kecil - berkisar antara 0,6 hingga $2 \mathrm{~m}^{3}$ - dengan proses pengisian umumnya dilakukan di atas daratan yang kemudian diletakkan di tempat rencana (Gambar 8).

Geobag umumnya diaplikasikan pada daerah yang mengalami abrasi yang tidak terlalu berat dan yang memerlukan penanganan segera untuk jangka waktu pemakaian yang tidak terlalu panjang. Umumnya material geotekstil yang digunakan harus distabilisasikan terhadap pengaruh sinar ultra violet, namun bagaimanapun konstruksi ini tetap harus dilindungi dari pengaruh sinar matahari langsung dengan cara ditutupi dengan material lain seperti batu-batuan.

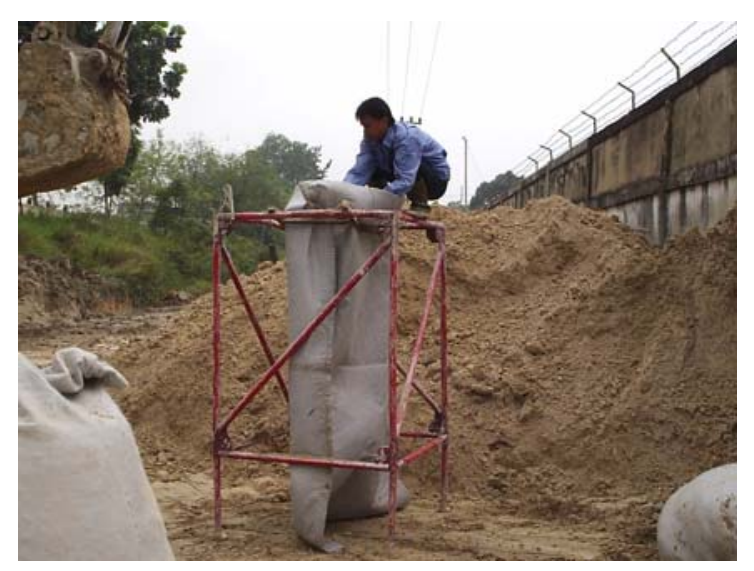

a. Pengisian geobag di darat

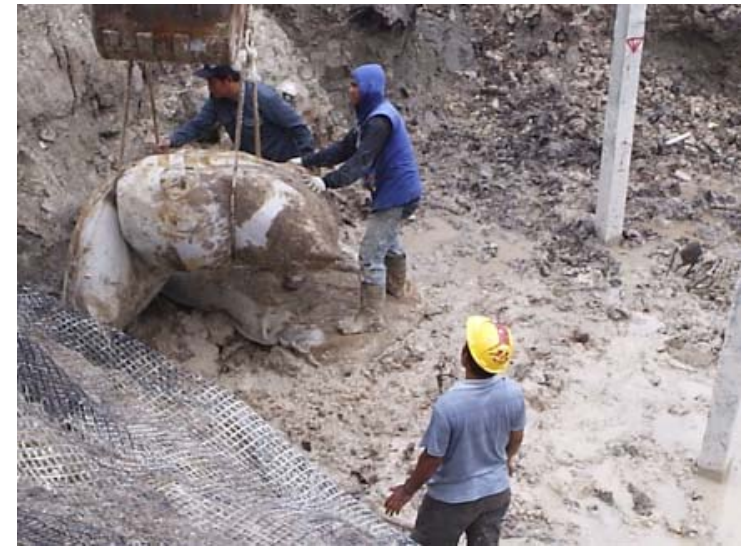

b. pemindahan geobag

Gambar 8 Proses pengisian dan pemindahan geobag

Jenis konstruksi kedua adalah geotube. Ini berbentuk turbular yang digunakan pada di daerah daratan atau daerah dengan tinggi air tidak terlalu dalam. Ukuran geotube juga sangat bervariasi dengan panjang berkisar antara 10 - 150 meter dan diameter rata - rata 1 - 5 meter dalam kondisi 
bulat sempurna. Instalasi dapat dilakukan di daerah kering maupun pada kedalaman air hingga lima meter. Gambar 9 berikut ini merupakan gambaran dari bentuk tipikal konstruksi geotube.

Geotube merupakan struktur yang cukup banyak diaplikasikan dan dilakukan analisis untuk menanggulangi berbagai permasalahan abrasi di banyak negara, termasuk di beberapa negara di Asia seperti Korea Selatan, Singapura, Jepang, Malaysia dan negara Asia lainnya, termasuk Indonesia.
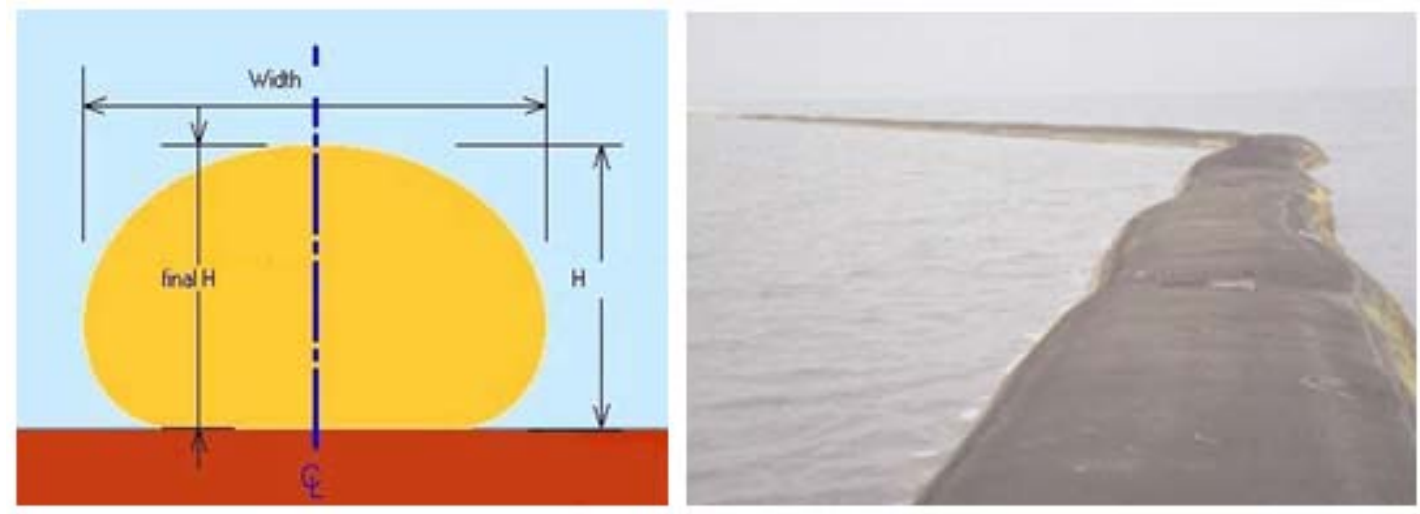

Gambar 9 Tipikal konstruksi geotube (Sumber: brosur TenCate).

Jenis konstruksi ketiga adalah geocontainer. Ini merupakan jenis geotextile containment bervolume besar dengan proses pengisian dalam barge di atas air dan kemudian dijatuhkan ke dalam air. Geocontainer seperti yang ditunjukkan pada Gambar 10 mempunyai ukuran diameter yang lebih besar dibandingkan jenis geotextile containment lain; umumnya disesuaikan dengan ukuran kapal hooper. Pasir atau material timbunan lainnya diisikan ke dalam geocontainer yang dilapisi geotekstil kemudian dijahit. Geocontainer dijatuhkan ke dasar laut dengan hooper. Penggunaan geocontainer umumnya untuk kedalaman air lebih dari lima meter.
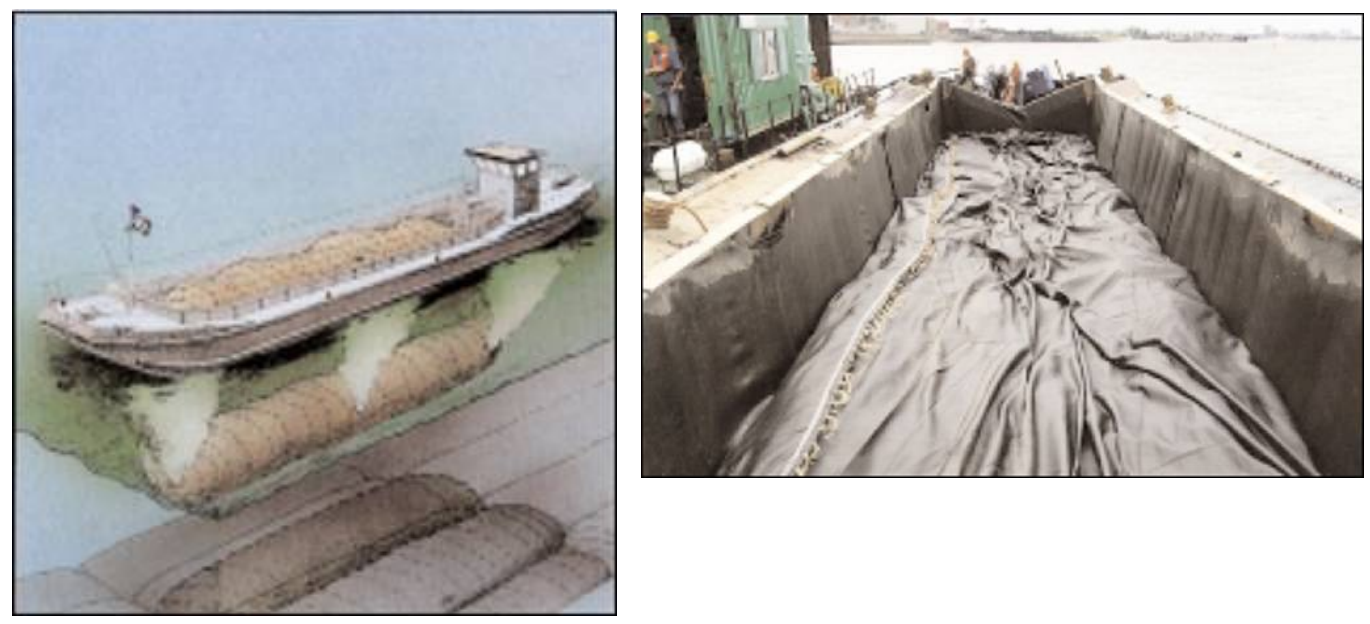

Gambar 10 Geocontainer (Sumber: brosur TenCate)

\section{Geotekstil}

Geotekstil adalah salah bagian dari geosintetik yang merupakan material dari bahan sintetik berbentuk lembaran dan tembus air. Dari proses pembuatannya secara umum ada dua jenis material 
geotekstil yaitu geotekstil woven dan geotekstil nonwoven. Geotekstil woven atau geotekstil teranyam merupakan jenis material geotekstil yang proses pembuatannya dilakukan dengan cara dianyam sehingga membentuk satu lembaran dengan serat-serat yang tersusun rapi, sedangkan proses pembuatan geotekstil nonwoven atau geotekstil tak teanyam dilakukan dengan cara menghamparkan gumpalan-gumpalan benang yang kemudian disatukan membentuk lembaran. Umumnya geotekstil woven mempunyai kekuatan tarik yang lebih baik jika dibandingkan geotekstil nonwoven namun sebaliknya geotekstil nonwoven mempunyai daya tahan yang lebih baik terhadap kerusakan akibat benda-benda tajam jika dibandingkan dengan geotekstil woven. Seiring dengan perkembangan teknologi dan waktu, kemudian diciptakan satu produk geotekstil yang memadukan kedua fungsi utama dari geotekstil woven dan geotekstil nonwoven, yaitu memiliki properti yang memadai baik pada kekuatan tarik maupun ketahanan terhadap kerusakan akibat benda-benda tajam yang dikenal dengan nama geotekstil komposit. Gambar 11 di bawah inimerupakan contoh-contoh material geotekstil.

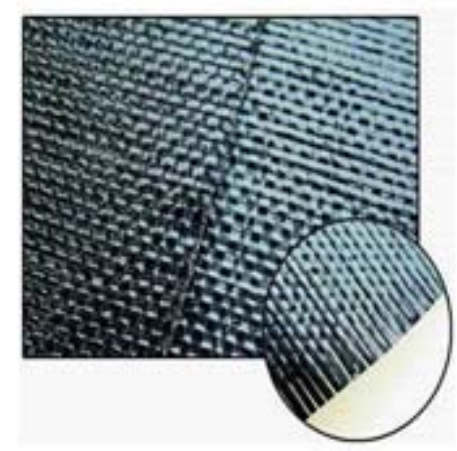

Geotekstil woven

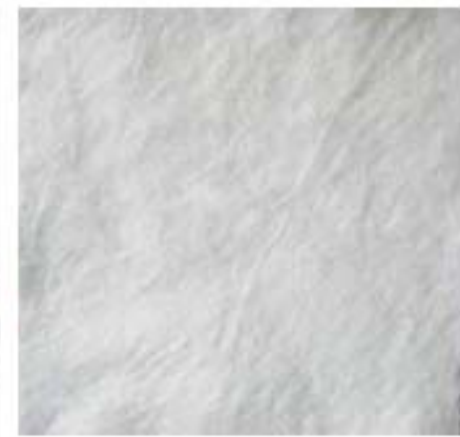

Geotekstil nonwoven

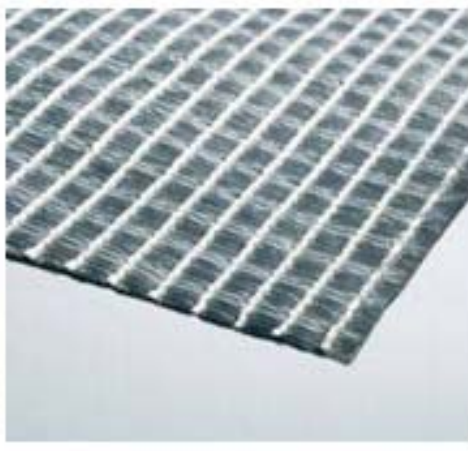

Geotekstil komposit

Gambar 11 Contoh material geotekstil

\section{Kontribusi Material Geosintetik pada Proses Reklamasi Pantai}

Terkait dengan pekerjaan reklamasi, kontribusi dari material geotekstil pada beberapa aplikasi atau terkait dengan fungsi geotekstil sebagai berikut:

\section{Meningkatkan Stabilitas Timbunan}

Penggunaan material geotekstil pada konstruksi timbunan (reklamasi) di atas tanah lunak, yaitu dengan cara meletakkan lembaran geotekstil di dasar timbunan dapat meningkatkan stabilitas timbunan(Gambar 12). Prinsip penggunaan material geosintetik dalam perkuatan dasar timbunan adalah mengandalkan kekuatan tarik material yang diletakkan sedemikian rupa sehingga memotong garis kelongsoran yang diperkirakan akan terjadi.

\section{Lapis Filtrasi dan Separasi}

Struktur geotekstil yang dibentuk sedemikian rupa menjadikan material geotekstil mempunyai kemampuan untuk memisahkan dua material yang berbeda dan sekaligus berfungsi sebagai penyaring (Gambar 13) - air dimungkinkan lolos, sedangkan partikel tanah akan tertahan.

\section{Mengurangi Pencemaran saat Reklamasi}

Perkembangan aplikasi dari penggunaan material geotekstil cukup pesat dan sangat beragam. Dengan mengandalkan kemampuan filtrasi dan separasi yang baik, geotekstil juga dapat diaplikasikan 
untuk mencegah atau mengurangi pencemaran air laut pada saat proses reklamasi dilaksanakan. Sistem ini dikenal dengan nama "silt curtain", yaitu dengan meletakkan material geotekstil secara vertikal dan pada sisi atas geotekstil diletakkan pelampung-pelampung (Gambar 14).

Pada kondisi dengan tinggi gelombang yang cukup ekstrim, sistem ini umumnya dilengkapi dengan angkur-angkur pengaku disamping penggunaan pemberat pada bagian bawah sistem.

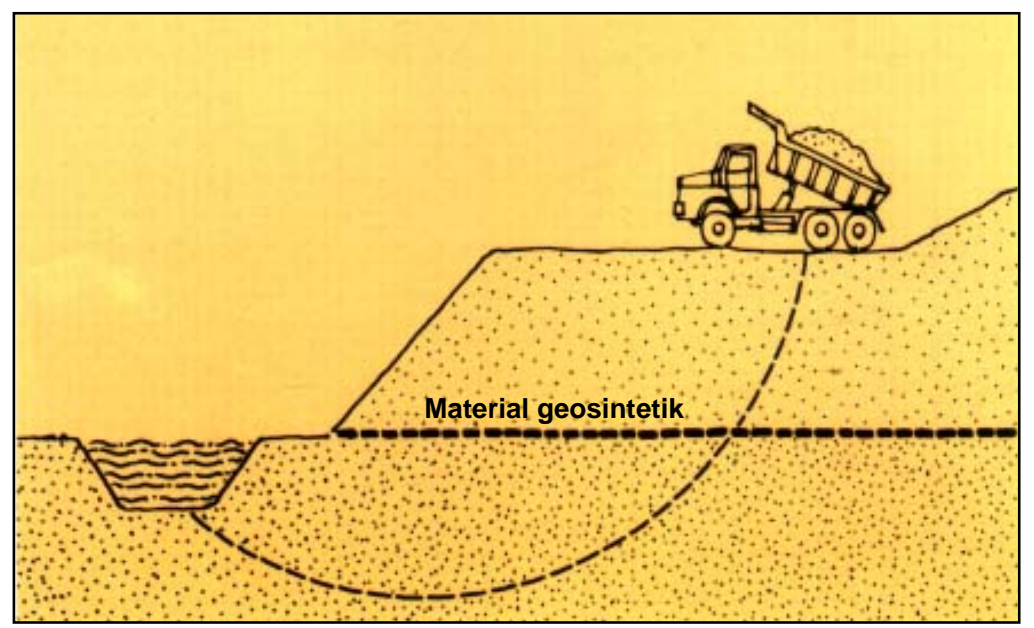

Gambar 12 Prinsip kerja geotekstil untuk meningkatkan stabilitas konstruksi timbunan

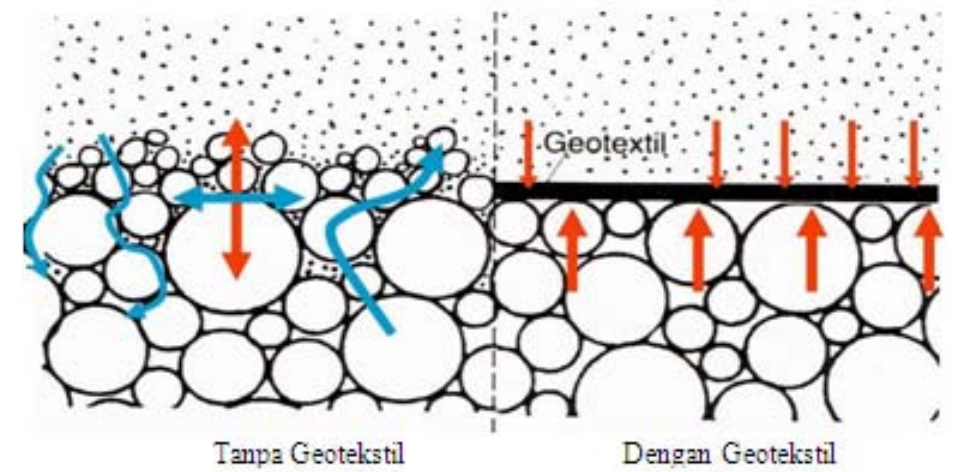

Gambar 13 Prinsip kerja geotekstil sebagai lapisan filtrasi dan separasi
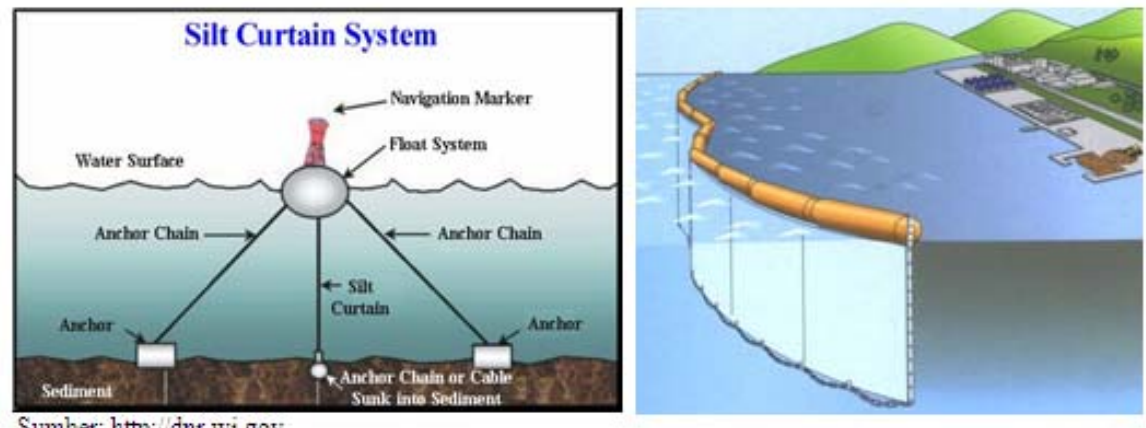

Gambar 14 Contoh sistem dan proyek Silt Curtain 


\section{Vertikal Drain sebagai Solusi}

Permasalahan yang dapat terjadi adalah penurunan tanah dasar yang dapat berlangsung dalam jangka waktu yang sangat lama. Salah satu alternatif solusi untuk mengatasi permasalahan ini adalah pemasangan vertikal drain (Indraratna, 2008). Prinsip kerja dari material ini adalah mempercepat terjadinya proses konsolidasi dengan menyediakan jalur-jalur vertikal untuk mengeluarkan air tanah dari lapisan tanah dasar yang lunak, sehingga air tanah akan terperas keluar dan tanah dasar akan mengalami penurunan akibat terjadinya proses konsolidasi pada lapisan tanah lunaknya. Gambar 15 berikut ini menyajikan ilustrasi dari pergerakan air tanah pada proses penurunan dengan dan tanpa vertikal drain. Dengan terjadinya penurunan pada tanah dasar tersebut, tanah dasar akan memampat dan kuat geser tanah akan meningkat sehingga kapasitas daya dukung tanah dasar juga meningkat.

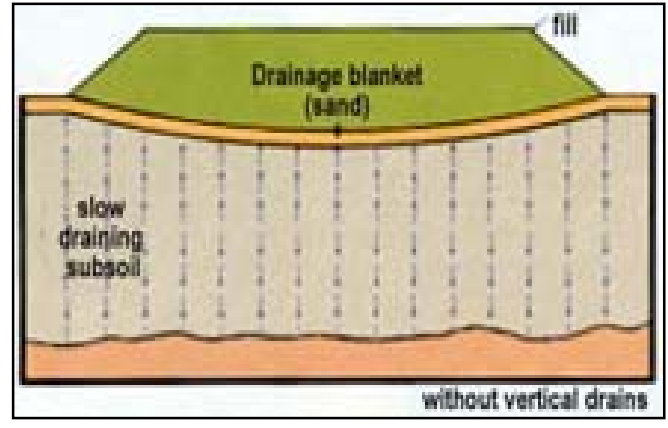

Tanpa vertikal drain, proses penurunan konsolidasi akan berjalan lambat dan lama

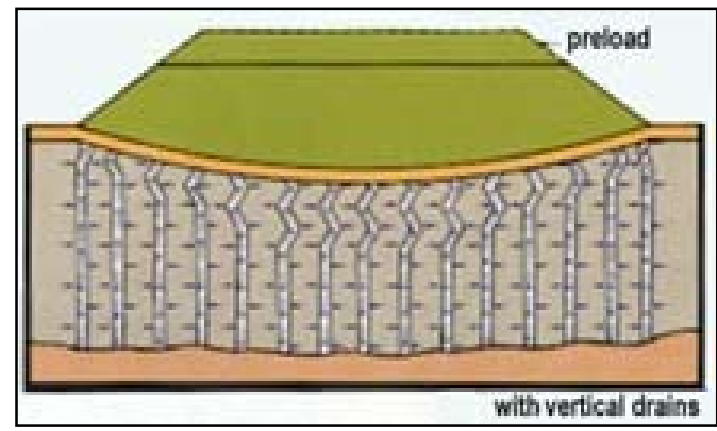

Dengan vertikal drain, penurunan konsolidasi akan berjalan cepat dan singkat

Gambar 15 Prinsip kerja vertikal drain

\section{Perancangan Aplikasi Material Geosintetik pada Reklamasi Pantai}

Beberapa pertimbangan dan data yang diperlukan dalam perancangan aplikasi material geosintetik pada pekerjaan reklamasi pantai adalah sebagai berikut: (1) bathymetri dasar laut; (2) geometri rencana tinggi reklamasi; (3) beban luar yang bekerja pada struktur reklamasi; (4) hasil investigasi tanah dasar (tes sondir/tes SPT); (5) hasil uji laboratorium lengkap tanah dasar; (6) ketinggian gelombang dan pasang surut air laut; (7) parameter material pengisi geotekstil tube; (8) material tanah reklamasi yang digunakan; (9) stabilitas geotextile containment saat bencana atau badai; (10) ukuran bukaan material geotekstil yang digunakan berkaitan dengan ukuran material pengisi; (11) kuat tarik perlu material geotekstil, termasuk juga kekuatan sambungannya

Urutan pekerjaan aplikasi geosintetik pada pekerjaan reklamasi adalah sebagai berikut: (1) pengisian dan pemasangan geotube yang berfungsi sebagai dinding penahan tanah; (2) pengelaran geotekstil yang berfungsi sebagai perkuatan dan atau separasi; (3) pengisian material timbunan setinggi konstruksi geotube; (4) pemasangan vertikal drain untuk mempercepat proses konsolidasi tanah dasar yang lunak; (5) pemberian beban (preloading) sebagai sarana pada sistem percepatan konsolidasi menggunakan vertikal drain. Untuk lebih jelasnya lihat Gambar 16 di bawah ini. 


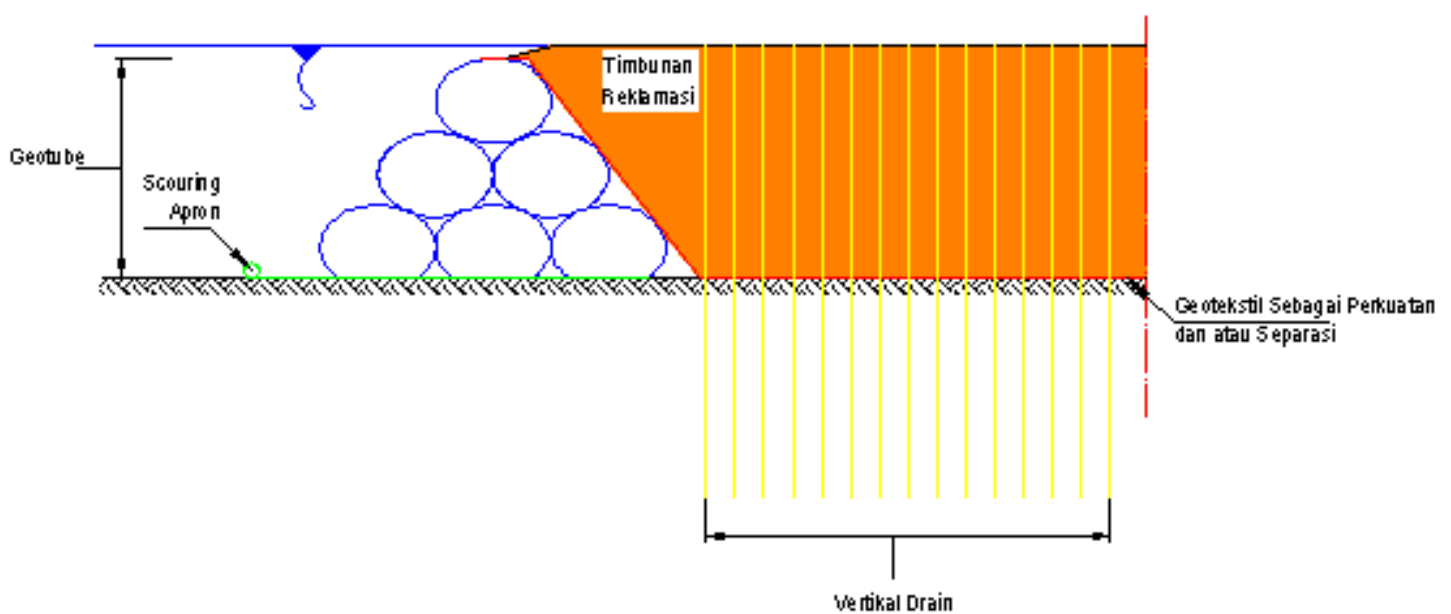

Gambar 16 Sketsa aplikasi geosintetik pada pekerjaan reklamasi

\section{PENUTUP}

Penggunaan material geosintetik sebagai material konstruksi tambahan pada pekerjaan reklamasi pantai memberikan banyak manfaat mulai dari tingkat keekonomisan, kecepatan pelaksanaan yang tinggi, dampak terhadap lingkungan yang relatif minimum hingga biaya pemeliharaan yang relatif rendah.

\section{DAFTAR PUSTAKA}

Das, B.M. (2001). Principles of Geotechnical Engineering (5 ${ }^{\text {th }}$ ed.). London: Thomson Learning.

Direktorat Jenderal Kelautan, Pesisir dan Pulau-Pulau Kecil. (2005). Pedoman Reklamasi di Wilayah Pesisir. Jakarta: Direktorat Jenderal Kelautan, Pesisir dan Pulau-Pulau Kecil.

Indraratna, B. (2008). Recent advancements in the use of prefabricated vertical drains in soft soils. Australian Geomechanic Journal, March 2008.

Koerner, R.M. (2005). Designing with Geosynthetics ( $5^{\text {th }}$ ed.). New Jersey: Prentice Hall.

Lawson, C. (2012). Geosynthetics for riverbank and coastal protection in Asia. $5^{\text {th }}$ Asian Regional Conference on Geosynhtetics, 10 - 14 December 2012, Bangkok, Thailand. 